\title{
Angklung Sunda Sebagai Wahana Industri Kreatif dan Pembentukan Karakter Bangsa
}

\author{
Oleh \\ Deni Hermawan, dkk. ${ }^{\mathrm{i}}$ \\ STSI Bandung \\ Jl. Buahbatu 212 Bandung \\ E-mail: denihermawan59@gmail.com
}

\begin{abstract}
The terminology of Angklung has two different meanings: as an instrument and as a form of performing arts. As an instrument, Angklung is an instrument made of bamboo and played by shaking it. As a form of performing art, Angklung is a form of performing art which uses instruments called Angklung. Either as an instrument or as a form of performing arts, Angklung is rich of values, such as the values of economic, social, cultural, education, ethics, morality, etc., which are closely related to cretive industries and nation character building. The purpose of this article is to examine the possibility for Angklung to be used as medium for creative industries and nation character education.
\end{abstract}

Key words: Angklung, creative industry, nation character building

\begin{abstract}
ABSTRAK
Istilah Angklung memiliki dua pengertian yang berbeda: sebagai alat musik dan sebagai bentuk seni pertunjukan. Sebagai alat musik, Angklung ialah sebuah alat musik yang terbuat dari bambu dan dimainkan dengan cara digoyangkan. Sebagai bentuk seni pertunjukan, Angklung ialah sebuah bentuk seni pertunjukan yang menggunakan alat musik yang disebut Angklung. Baik sebagai alat musik maupun sebagai bentuk seni pertunjukan, Angklung kaya akan nilai, seperti nilai ekonomi, sosial, budaya, pendidikan, etika, moral, dan lain-lain, yang sangat berkaitan dengan industri kreatif dan pembentukan karakter bangsa. Tujuan dari tulisan ini adalah untuk mengetahui kemungkinan pemanfaatan Angklung sebagai media untuk industri kreatif dan pembentukan karakter bangsa.
\end{abstract}

Kata kunci: Angklung, industri kreatif, pembentukan karakter bangsa

\section{PENDAHULUAN}

Orang Sunda, yang merupakan bagian kecil dari penduduk Indonesia yang beraneka ragam bahasa dan kebudayaannya, dikenal sebagai masyarakat yang religius, ramah, rendah hati, suka mengalah, tidak suka menonjolkan diri, suka menolong, dan karakter-karakter positif lainnya.
Oleh karena karakter-kereakter positif inilah orang Sunda yang tinggal di beberapa wilayah di Propinsi Jawa Barat dan Banten bisa hidup tenang, damai, dan sejahtera. Akan tetapi perilaku positif yang telah lama melekat dalam kehidupan dan telah menjadi kepribadian orang Sunda ini semakin hari semakin kabur, semakin tidak jelas, dan pada akhirnya dewasa ini 
berganti dengan perilaku yang cenderung negatif, menyimpang dari karakter atau perilaku mulia dan terpuji. Sebagian dari mereka sudah tidak peduli lagi akan nilainilai moralitas yang baik, dan membiarkan dirinya terseret ke dalam kehidupan yang penuh dengan pelanggaran terhadap ajaran agama, hukum, adat-istiadat, moral, etika, dan norma-norma kehidupan di masyarakat. Budaya kekerasan dalam berbagai bentuk yang menyebabkan terenggutnya hak asasi orang lain telah menjadi fenomena sehari-hari dalam kehidupan orang Sunda, bahkan etnis-etnis lainnya di Indonesia.

Salah satu faktor penyebab terjadinya degradasi moral ini adalah kepribadian orang Sunda yang semakin terpengaruh oleh sisi-sisi negatif dari kehidupan yang semakin modern dan global. Kemajuan ilmu pengetahuan dan teknologi, juga globalisasi, di samping menimbulkan pengaruh positif, juga pengaruh negatif. Sebagai salah satu contoh kasus, misalnya dampak dari kemajuan ilmu pengetahuan dan teknologi di bidang komunikasi dan informasi, yakni televisi dan internet. Pola hidup kapitalisme, yakni komersialisme dan konsumerisme Barat yang telah merasuki kehidupan bangsa Indonesia telah menyebabkan acara-acara telivisi lebih cenderung berorientasi pada komersialisme pasar. Akibatnya, sebagian besar acara-acara tayangan televisi, terutama sinetron, hanya bertujuan untuk memenuhi selera pasar dan hiburan semata, hampir tidak ada ruang bagi pemirsa untuk mengapresiasi serta menghayati nilai-nilai tradisi, kearifan lokal, moralitas, dan budaya bangsa. Sinetron, misalnya, kebanyakan tidak lebih dari sekedar menayangkan percintaan anak remaja, tindakan kekerasan dalam rumah tangga, perenggut- an hak asasi manusia, kehidupan mewah dan glamor, dsb. Hal ini semua sama sekali tidak memberikan pembelajaran dan apresiasi yang mengarah pada kecintaan terhadap budaya dan bangsa. Demikian pula halnya dengan internet. Di samping memberikan manfaat yang cukup besar, yang antara lain mempermudah komunikasi dan akses terhadap berbagai ilmu pengetahuan, juga memberikan dampak negatif manakala fasilitas internet disalahgunakan untuk melakukan berbagai bentuk penipuan untuk mendapatkan keuntungan, baik dalam bentuk material maupun nonmaterial.

Globalisasi yang berdampak pada kehidupan eknomi negara berkembang seperti halnya Indonesia telah menyebabkan semakin besarnya jurang pemisah antara si miskin dan si kaya dalam berbagai tingkatan, dalam tingkatan antarnergara (bangsa), antarmasyarakat, antarkelompok, dan antarindividu. Tayangan di berbagai stasiun televisi yang berorientasi pada kebutuhan pasar (komersialisme) telah menyebabkan ketimpangan frekuensi penayangan antara kesenian modern (Barat) yang secara ekonomi menguntungkan dan kesenian tradisional (daerah) yang kurang (bahkan mungkin tidak) menguntungkan bagi pihak televisi. Hal ini berdampak pada ketimpangan kehidupan ekonomi antara seniman modern (pop, Barat) dan seniman tradisi (daerah). Oleh sebab itu, banyak seniman tradisi yang hidupnya serba kekurangan karena profesinya sebagai seniman tradisi tidak dapat menjamin kehidupan ekonominya, dan seni di sini lebih cenderung hanya berfungsi untuk memenuhi hasrat kesenimanannya (sebagai hobi) daripada untuk memenuhi kebutuhan ekonominya.

Globalisasi, yang disertai dengan ke- 
majuan ilmu pengetahuan dan teknologi di bidang komunikasi dan informasi, selain berdampak pada kehidupan ekonomi, juga bedampak pada kehidupan sosial budaya bangsa Indonesia. Berbagai informasi yang tersedia di layanan internet, akses komunikasi dengan berbagai pihak, baik antarorganisasi maupun antarindividu, melalui jejaring sosial facebook di seluruh dunia tidak jarang melahirkan perilaku yang menyimpang dari tatanan moral bangsa. Dampak globalisasi bagi kehidupan ekonomi bangsa yang semakin terpuruk telah menyebabkan terjadinya PHK, putus sekolah, kebodohan, pengangguran, kemiskinan, yang kemudian melahirkan berbagai tindakan kriminalitas. Sekarang ini sebagian masyarakat Indonesia, termasuk sebagain orang Sunda, telah kehilangan karakter positif yang kemudian mengakibatkan terjadinya krisis jati diri, krisis kepribadian yang mengarah pada terjadinya degradasi moral bangsa.

Masalah keterpurukan ekonomi dan degradasi moral bangsa tersebut hendaknya secepatnya ditanggulangi dengan melakukan berbagai upaya dan pendekatan yang dipandang sesuai, salah satunya adalah dengan upaya pendidikan melalui pendekatan budaya. Pendidikan yang dimaksud adalah pendidikan (pembangunan atau pembentukan) karakter bangsa, sedangkan yang dimaksud dengan pendekatan budaya adalah penggunaan salah satu jenis kesenian tradisional sebagai wahana atau sarana pendidikan yang sekaligus juga sebagai sarana pemenuhan kebutuhan ekonomi dalam bentuk industri kreatif. Salah satu jenis kesenian yang dipandang dapat memenuhi kebutuhan tersebut, yakni dapat digunakan sebagai wahana pendidikan karakter bangsa dan pemenuhan kebutuhan ekonomi dalam bentuk industri kreatif adalah Angklung Sunda.

Tulisan ini bermaksud untuk menginformasikan hasil penelitian/pengkajian terhadap kemungkinan Angklung untuk dijadikan wahana industri kreatif dan wahana pembentukan karakter bangsa, dengan pertanyaan penelitian: 1) mengapa serta sejauh mana Angklung dapat dijadikan sebagai wahana indiustri kreatif?; dan 2) mengapa serta sejauh mana Angklung dapat dijadikan sebagai wahana pembentukan karakter bangsa? Untuk memperoleh jawaban terhadap pertanyaan penelitian tersebut telah dilakukan penelitian dengan menggunakan metode kualitatif. Sesuai dengan karakteristik penelitian kualitatif, penelitian Angklung Sunda dilakukan di tempat tumbuh dan berkembangnya Angklung tersebut yang memiliki latar/lingkungan alami, yaitu lingkungan alamiah Angklung yang tumbuh dan berkembang di masyarakat Sunda. Pengumpukan data di lapangan dilakukan dengan menggunakan teknik penelitian lapangan yang sudah umum dipakai dalam proses penelitian, yaitu melalui: studi kepustakaan, wawancara, observasi, perekaman, dan pengambilan gambar (foto).

\section{PEMBAHASAN}

\section{A. Angklung Sebagai Wahana Industri Kreatif}

a. Sebagai Alat Musik

Dalam kapasitasnya sebagai alat musik, Angklung merupakan satu bentuk alat musik yang terkena sentuhan kreatif. Dalam arti, Angklung merupakan satu bentuk alat musik hasil kreativitas individu pembuatnya. Sebagai satu bentuk alat 
musik yang terkena sentuhan kreatif, hal ini terbukti dari variasi bentuk alat musik tersebut. Sebagai contoh kasus, di bawah ini dapat dilihat beberapa variasi bentuk Angklung, yaitu: Angklung standar (Angklung Daeng/Udjo), Angklung Dogdog Lojor, Angklung Baduy, Angklung Buncis Banten Kidul, Angklung Buncis Cigugur, Angklung Gubrag, dan Angklung Badeng.

Bentuk dasar Angklung di atas semuanya sama, terdiri dari susunan potongan bambu bernada dan rangka (bingkai) tempat meletakkannya, seperti Angklung Daeng/Udjo. Akan tetapi yang membuat perbedaan di antara Angklung-Angklung tersebut adalah variasi bentuk rangka dan hiasannya, yang tentu saja hal ini merupakan hasil kreativitas pembuatnya. Angklung Dogdog Lojor, misalnya, bagian atas rangkanya berbentuk lengkungan dengan hiasan daun pelah. Demikian pula halnya dengan Angklung Baduy dan Angklung Buncis Banten Kidul. Angklung Gubrag, hiasannya masih menggunakan daun pelah. Akan tetapi bentuk rangkanya berbeda. Kemudian Angklung Buncis Cigugur, hiasan rangkanya sudah lain lagi, demikian pula halnya dengan Angklung Badeng yang hiasannya terbuat dari kain yang dibentuk sedemikian rupa yang berfungsi sebagai penutup ujung rangka.

Perbedaan yang tampak pada ketujuh Angklung di atas bukan hanya terbatas pada rangkanya, melainkan juga pada banyaknya tabung (nada) Angklung, ada yang hanya terdiri dari dua tabung, seperti Angklung Buncis Banten Kidul dan Angklung Buncis Cigugur; ada yang terdiri dari tiga tabung, seperti salah satu Angklung Daeng/Udjo, Angklung Dodgdog Lojor, Angklung Baduy, Angklung Gubrag, dan Angklung Badeng; dan ada pula yang terdiri dari empat tabung seperti
Angklung Daeng/Udjo. Perbedaan jumlah tabung ini tentu saja disesuaikan dengan kebutuhan musikal. Angklung yang terdiri dari dua tabung hanya menghasilkan satu nada dengan nada oktafnya, Angklung yang terdiri dari tiga tabung dapat menghasilkan satu nada dengan dua nada oktafnya, dan Angklung yang terdiri dari empat tabung (Angklung Daeng/Udjo), selain dapat menghasilkan satu nada dengan dua nada oktafnya, juga ditambah dengan nada lain sehingga membentuk akor.

Dengan demikian, jelaslah bahwa bentuk Angklung sangatlah bervariasi. Variasi tersebut khususnya terletak pada bentuk rangka dan hiasannya, dan juga pada jumlah tabung (nada) Angklung. Perbedaan (variasi) tersebut jelas merupakan hasil kreativitas pembuatnya disesuaikan dengan kebutuhan musikal dan estetika pertunjukan agar terlihat lebih indah dan menarik.

Kemudian, Angklung merupakan satu unsur dari pasar barang seni dan satu bentuk kerajinan. Sebagai satu unsur barang seni dan satu bentuk kerajinan, artinya Angklung merupakan salah satu benda, barang, atau hasil karya seni (kerajinan) yang dapat diperjualbelikan, baik dalam bentuk alat musik itu sendiri (untuk digunakan dalam pertunjukan) maupun dalam bentuk cinderamata (Angklung berukuran kecil untuk hiasan atau gantungan kunci). Angklung seperti ini dapat ditemukan di Saung Angklung Udjo. Saung Angklung Udjo merupakan salah satu objek wisata yang menjadi tujuan orang asing dari mancanegara. Orang asing yang berkunjung ke Saung Angklung Udjo disuguhi rangkaian acara pertunjukan, khususnya pertunjukan Angklung. Selain menyajikan pertunjukan Angklung dan kesenian tradisional lainnya, seperti tari dan wayang 
golek, Saung Angklung Udjo juga menyediakan barang-barang suvenir atau cinderamata. Salah satu dari sekian banyak cinderamata dimaksud adalah Angklung mini atau Angklung berukuran kecil yang biasa digunakan sebagai hiasan atau gantungan kunci.

\section{b. Sebagai Bentuk Kesenian}

Dalam kapasitasnya sebagai satu bentuk kesenian, Angklung merupakan satu bentuk kesenian yang juga terkena sentuhan kreatif. Sentuhan kreatif ini tampak pada variasi bentuk penyajian Angklung oleh para senimannya. Pada umumnya Angklung buhun (tradisional) seperti halnya Angklung Dogdog Lojor, Angklung Buncis, Angklung Badeng, Angklung Badud, Angklung Gubrag, dan Angklung buhun lainnya ditampilkan dalam bentuk helaran, atau berjalan kaki keliling kampung dalam rangka upacara ritual padi atau syukuran khitanan. Akan tetapi ada juga yang disajikan di tempat tertentu, misalnya di tempat pertunjukan khusus, di dalam ruangan atau di atas panggung. Angklung Udjo, misalnya, selain dipertunjukkan dalam bentuk arak-arakan, berkeliling di arena pertunjukan, ada juga yang dipertunjukan secara statis (diam) di satu tempat pertunjukan tertentu. Angklung yang dipertunjukkan dalam bentuk arak-arakan, berpura-pura mengarak anak yang disunat, misalnya Angklung tradisional; sedangkan Angklung yang dipertunjukkan secara statis di satu tempat tertentu, misalnya Angklung Sunda/ Indonesia, yaitu Angklung "modern" yang bertangga nada pentatonik dan heptatonik, yang bisa memainkan lagu-lagu daerah (berlaras pelog, salendro, dan madenda) dan lagu-lagu Indonesia/asing yang bertangga nada musik Barat).
Kemudian, ada pula Angklung yang dipertunjukkan secara statis (diam) di satu tempat, biasanya di ruangan terbuka, tetapi disertai dengan atraksi/permainan. Angklung Badud, dari Cijulang, ii Kabupaten Ciamis, misalnya, di samping disajikan dalam bentuk arak-arakan, juga disajikan dalam mengiringi atraksi, yakni atraksi peran berbagai jenis binatang, seperti lutung, kera, anjing hutan, babi hutan, dan harimau; barongsay, kakek-kakek, nenek-nenek, dan kuda lumping. Atraksi ini dipimpin oleh seorang pawang yang bertugas mengundang roh leluhur, spirit, atau setan agar merasuk ke dalam tubuh para pemain peran binatang tersebut sehingga mereka mendem (kesurupan), dan kemudian menyembuhkan para pemain peran tersebut, membebaskannya dari pengaruh roh-roh yang merasukinya sehingga menjadi sadar kembali. Jadi, atraksi atau permainan peran binatang tersebut dilakukan dalam keadaan kerasukan, tidak sadar. Dalam keadaan tidak sadar, para pemain melakukan berbagai macam perilaku binatang yang diperankannya dan memakan makanan yang biasa dimakan oleh binatang yang diperankannya. Pada saat permainan dianggap cukup, sang pawang pun menyembuhkan kembali para pemain peran yang kesurupan sehingga mereka menjadi sadar kembali, dan permainan Angklung Badud pun selesai.

Demikian pula halnya dengan Angklung Badeng dari Desa Sanding, Kabupaten Garut. Dulu, Angklung Badeng dipertunjukkan dalam fungsinya sebagai media penyebaran agama Islam. Sekarang, pertunjukannya hanya berfungsi sebagai hiburan dalam memeriahkan acara pesta dan syukuran. Pertunjukan Angklung Badeng adalah berupa penampilan lagu-lagu islami (yang dulu digunakan 
sebagai media penyebaran agama Islam) yang disertai dengan tarian yang mengutamakan gerak langkah.

Berdasarkan kajian terhadap Angklung, baik sebagai alat musik maupun sebagai kesenian, dalam kaitannya dengan aspek-aspek industri kreatif (ekonomi), tampaknya sangatlah tepat apabila Angklung dijadikan sebagai wahana industri kreatif. Sebagai wahana industri kreatif, artinya bahwa Angklung dalam hal ini, baik dalam kapasitasnya sebagai alat musik maupun sebagai satu bentuk kesenian, harus bisa dijadikan objek kreativitas oleh individu atau komunitas, yang kemudian dari tindakan kreativitasnya ini dapat menghasilkan finansial untuk meningkatkan kesejahteraan ekonomi individu atau komunitas tersebut. Di sisi lain, individu atau komunitas ini pun harus mampu melakukan tindakan kreativitas dimaksud, baik dalam pembuatan Angklung maupun dalam penggarapan pertunjukan Angklung.

Sebelum melakukan tindakan kreativitas pada Angklung, tentu saja invidu ataupun komunitas ini harus mampu dulu membuat Angklung dan menyajikan Angklung. Untuk memperoleh pengetahuan praktis tentang cara membuat Angklung, dapat dilihat serta dipelajari bagaimana caranya melalui DVD-nya (DVD 1) yang disertakan sebagai pelengkap laporan penelitian ini. Dalam DVD 1 yang berjudul "Proses Pembuatan Angklung Sunda Sebagai Wahana Industri Kreatif" tersaji proses pembuatan Angklung dari mulai penjelasan mengenai penebangan bambu untuk bahan Angklung hingga terbentuk menjadi Angklung, dan dilanjutkan dengan menampilkan contoh-contoh bentuk Angklung hasil kreativitas pembuatnya.

Dalam DVD1 tersebut tampak bagaima- na langkah-langkah pembuatan Angklung dari awal sampai akhir yang dilakukan oleh Ujang Hidayat, perajin Angklung yang tinggal di Padasuka Bandung, yang dijadikan sebagai narasumber penelitian. Dari hasil pengamatan terhadap apa yang dilakukan Ujang Hidayat, diperoleh informasi mengenai langkah-langkah pembuatan Angklung yang secara singkat dapat dijelaskan sebagai berikut:

Pertama, untuk bahan pembuatan Angklung perlu menebang bambu terlebih dahulu. Penebangan bambu tidak dapat dilakukan pada sembarang waktu. Penebangan bambu yang baik dilakukan pada musim kemarau kira-kira pk. 9.00. Pada saat ini, air yang terkandung dalam bambu sudah turun. Jadi, bambu yang akan ditebang tidak terlalu basah, sudah mulai kering. Setelah ditebang, bambu tersebut disimpan diberdirikan selama satu minggu, dilanjutkan dengan proses pengeringan untuk beberapa lama. Pada saat pengeringan, bambu tidak boleh kena sinar matahari secara langsung, untuk menjaga agar bambu warnanya sama, rata, tidak belang (berwarna-warni) yang disebabkan oleh terkena sinar matahari sebagian. Proses ini harus dilakukan dengan baik agar menghasilkan kualitas bambu yang baik untuk pembuatan Angklung.

Kedua, bambu yang ditebang untuk pembuatan Angklung terdiri dari beberapa jenis, di antaranya: bambu tali, bambu temen, dan bambu wulung (berwarna hitam). Ketiga jenis bambu tersebut baik sekali untuk bahan Angklung, walaupun tidak terlepas dari perbedaan. Bambu tali, misalnya, dagingnya tebal sehingga akan menghasilkan bunyi Angklung yang lembut; sedangkan bambu wulung dagingnya tipis sehinggga akan menghasilkan bunyi Angklung yang merdu, nyaring. 
Ketiga, bambu yang sudah kering kemudian diproses untuk dijadikan Angklung. Proses pembuatan Angklung dimulai dengan membuat tabung Angklung, kemudian dilaras, setelah beres dilanjutkan dengan membuat ancak atau dudukan Angklung. Terakhir, tabung-tabung Angklung yang sudah dibuat dipasangkan pada ancak, maka jadilah Angklung yang siap untuk dibunyikan.

Dalam DVD 1 ini juga diperlihatkan bermacam-macam Angklung berukuran kecil atau Angklung mini hasil kreativitas untuk hiasan dan cinderamata. AngklungAngklung yang tidak terlalu kecil digantungkan pada rak, ada yang disimpan di dalam kotak kaca, ada yang tidak. Ada pula yang diletakkan pada tempat menyimpan alat-alat tulis. Kemudian, Angklung yang berukuran sangat kecil digunakan sebagai hiasan/ornamen, disematkan pada baju di dada sebelah kiri atau sebelah kanan. Di samping itu, ada juga tabung-tabung Angklung yang berukuran biasa yang dibuat sebagai gantungan, dibunyikan dengan cara digoyangkan, yang berfungsi sebagai tanda/pemberitahuan. Angklung semacam ini biasanya digantungkan di depan pintu rumah, digoyangkan oleh orang yang hendak bertamu sebagai pemberitahuan kepada tuan rumah bahwa ada yang mau bertamu.

Proses pembuatan Angklung dan contoh-contoh bentuk Angklung berukuran kecil hasil kreativitas yang tersaji dalam DVD 1 sebagaimana diuraikan di atas merupakan hal yang dapat dijadikan sebagai bahan pembelajaran dalam rangka membangun industri kreatif yang diharapkan dapat membantu meningkatkan kesejahteraan ekonomi masyarakat, khususnya para perajin dan para seniman Angklung.

\section{B. Angklung Sebagai Wahana Pemben- tukan Karakter Bangsa}

\section{a. Sebagai Alat Musik}

Sebagai alat musik (bentuk fisik), Angklung memiliki makna, meliputi: makna filosofis dan makna religius, yang dapat dijadikan materi dalam pendidikan (pembentukan) karakter bangsa, baik di sekolah maupun di luar sekolah. Kedua makna tersebut perlu diinformasikan kepada peserta didik agar mereka mengetahui serta menyadari akan bagaimana pentingnya kedudukan, fungsi, nilai, dan makna Angklung di dalam kehidupan masyarakat, salah satunya masyarakat Kanekes.

Masyarakat Kanekes percaya bahwa dalam bentuk Angklung itu sendiri terkandung makna filosofis yang penting bagi masyarakatnya. Angklung dijadikan pandangan hidup yang tujuannya adalah untuk memahami etika kehidupan manusia dalam bermasyarakat. Angklung dijadikan simbol yang memiliki makna seperti terungkap dalam peribahasa atau babasan dalam bahasa Sunda: ulah ngelmu Angklung. Pengertian dari peribahasa tersebut kira-kira adalah 'jangan berilmu seperti Angklung'. Peribahasa tersebut isinya didasarkan pada posisi pemasangan tabung-tabung bambu pada Angklung itu sendiri. Dalam sebuah bingkai atau rangka Angklung terdapat paling sedikit dua tabung. Tabung Angklung yang besar atau yang juga dinamai Angklung indung akan selalu dipasang menghadap punggung (bagian belakang) tabung Angklung kecil atau Angklung anak, sebaliknya posisi Angklung kecil membelakangi tabung Angklung besar. Hal ini diartikan (dimaknai) bahwa perhatian atau kasih sayang ibu terhadap anaknya sangat besar, sebaliknya anak tidak terlalu memberikan perhatian kepada orang tuanya (ibunya), teta- 
pi lebih memberikan perhatian atau kasih sayang kepada anaknya.

Berdasarkan uraian tersebut, dapat ditarik kesimpulan bahwa makna filosofis dari peribahasa ulah ngelmu Angklung tersebut merupakan pesan moral yang sangat mendidik, yaitu agar setiap anak senantiasa memiliki etiket dan harus selalu teringat akan perhatian dan kasih sayang orang tuanya, mereka memiliki kewajiban untuk selalu hormat kepada orang tua, terutama kepada ibu.

Kemudian, masyarakat Kanekes memiliki kepercayaan bahwa bentuk Angklung digambarkan sebagai suatu lambang yang merujuk pada adanya konsep kosmos, yaitu kepercayaan terhadap adanya tiga lapisan kosmos atau dunia. Adapun ketiga lapisan kosmos tersebut tersusun sebagai berikut: Buana Nyungcung, Buana Panca Tengah, dan Buana Larang. Buana Nyungcung sebagai penggambaran dunia atas dilambangkan oleh bagian hiasan atas Angklung yang terbuat dari daun Pelah; Buana Panca Tengah sebagai gambaran dunia tengah yang merupakan tempat tinggal manusia dan makhluk hidup lainnya dilambangkan oleh bagian tabung; dan Buana Larang sebagai gambaran dunia bawah dilambangkan oleh soko.

Tiang-tiang Angklung sebagai kerangka tempat berdirinya tabung-tabung bambu dilambangkan sebagai suatu poros yang menghubungkan antara tiga lapisan dunia tersebut. Apabila dikaitkan dengan pendapat Mircea Eliade, poros tersebut disebut axis mundi. ${ }^{i i i}$ Di dalam kosmologi, poros tersebut sering dilambangkan sebagai tiang, tangga, pohon, gunung, dan sebagainya. Axis mundi ini terletak pada pusat dunia yang menembus tembok-tembok pemisah antarlapisan dunia. Melalui axis mundi inilah manusia religius dapat mengadakan hubungan dengan dunia atas dan dunia bawah.

Berdasarkan uraian di atas, tidaklah heran apabila Angklung (pertunjukan Angklung) digunakan dalam upacara ritual padi dan dipercaya sebagai media komunikasi antara manusia (orang Baduy) dan dewi padi (Dewi Sri) yang dipercaya sebagai makhluk spiritual yang mampu melindungi mereka, yakni memberi keselamatan dan kesejahteraan dalam bentuk hasil panen padi yang melimpah sebagai sumber kehidupan mereka.

\section{b. Sebagai Wujud Kesenian}

Sebagai kesenian (nonfisik), Angklung memiliki makna kultural (sebagai identitas bangsa) dan fungsi pendidikan, baik di dalam maupun di luar sekolah.

Angklung merupakan salah satu seni pertunjukan yang dijadikan kebanggaan oleh masyarakat Indonesia, khsusnya masyarakat Jawa Barat (dan Banten), terutama setelah resmi diakui oleh UNESCO sebagai salah satu the Intangible Culture Herritage (warisan budaya tak benda) bangsa Indonesia. Pengakuan dari UNESCO ini lebih mempertegas bahwa Angklung (tradisional dan modern) sudah menjadi identitas budaya bangsa Indonesia yang dianggap penting, karena kehadiran Angklung telah memberikan warna atau ciri/ identitas tersendiri bagi bangsa Indonesia, yakni sebagai masyarakat agraris tradisional yang juga mampu menyesuaikan dengan perkembangan zaman menuju kehidupan yang semakin "modern". Identitas ini sangat penting bagi setiap bangsa, termasuk bangsa Indonesia, sebagai upaya untuk meredam atau memfilter pengaruh dari semakin maraknya budaya pop di Indonesia yang di samping memiliki dampak positif, juga memiliki dampak 
negatif bagi kehidupan bangsa, terutama bagi kehidupan dan perkembangan kesenian tradisional di Indonesia.

Pengertian identitas sebagaimana dimaksud di atas memiliki cakupan yang cukup luas, salah satunya dapat dimaknai sebagai suatu hal yang melekat pada kehidupan manusia. Identitas merupakan suatu penanda yang dapat menjelaskan bahwa: inilah kami, inilah adat kami, inilah suku bangsa kami, inilah bangsa kami, dan sebagainya. Seni Angklung sudah menjadi bagian dari kehidupan masyarakat Indonesia yang tidak bisa dipisahkan dari sejarahnya. Angklung selalu dipertunjukkan, baik sebagai seni tradisional untuk menghormati Dewi Sri sebagai perlambang dari padi yang menjadi sumber kehidupan pokok masyarakat tertentu maupun sebagai seni "modern" untuk hiburan.

Angklung juga memiliki fungsi sebagai media pendidikan, baik di dalam maupun di luar sekolah. Seperti halnya alat-alat musik lainnya (gamelan, suling/rekorder, pianika/melodion, gitar, dst.), Angklung juga berfungsi sebagai media/alat bantu dalam mencapai tujuan pendidikan musik. Secara fundamental dalam pendidikan musik, Angklung dapat dijadikan sebagai salah satu alat musik yang digunakan dalam mengembangkan perasaan musikal, seperti: latihan pendengaran, latihan ritme, berimprovisasi, memahami bentuk musik (tema, motif, frase, gerak kalimat lagu secara keseluruhan, arsis dan tesis, rancang komposisi, dll.), dan latihan merasakan harmoni, akord atau polifoni. Permainan musik Angklung juga memiliki nilai-nilai pendidikan, di antaranya:

1) Nilai "berbuat", bahwa permainan Angklung lebih menonjol daripada alat lain;
2) Mendidik disiplin, tanggung jawab, saling harga-menghargai, kekompakan, dan kebersamaan;

3) Mengembangkan kepemimpinan, yakni dengan dibentuknya suatu formasi kelompok, di mana di dalamnya ada beberapa anggota yang berperanan lebih aktif daripada anggota yang lain, dan yang lebih dominan daripada yang lain, dan hal ini merupakan awal dari pembelajaran tentang kepemimpinana yang salah satunya ditunjukkan dengan adanya kelompok pemimpin dan pengikut.

4) Bermain musik melalui media Angklung dapat menemukan beberapa hal fundamental melalui saluran estetis dan emosional, dapat memenuhi kebutuhan pada pemakainya akan ekspresi musikal.

Penjelasan-penjelasan di atas menandaskan tentang pentingnya pelajaran musik di sekolah dengan memilih Angklung sebagai alternatifnya, baik diatonis maupun pentatonis, sebagai media pendidikan seni budaya yang mengusung pendidikan berkarakter bangsa Indonesia.

Angklung juga difungsikan sebagai media pendidikan di luar sekolah. Proses pendidikannya disampaikan secara nonformal. Pendidikan di masyarakat (luar sekolah) dilakukan secara perorangan atau kelompok, seperti di komunitas (kelompok daerah) tertentu sebagai sarana ritual (upacara), hiburan, atau pergaulan. Sedangkan pendidikan Angklung kreasi (modern/diatonis) banyak dilakukan di sanggar seni, lingkung seni, atau lembaga/ instansi yang memberi peluang kepada komunitas/lingkungannya dalam meningkatkan hubungan dalam sebuah organisasi modern dengan tujuan meningkatkan kemampuan mengapreasiasi karya seni 
tersebut menjadi sebuah seni pertunjukan.

Pendidikan Angklung di luar sekolah telah mewujudkan sebuah kreativitas yang memberikan dampak edukatif bagi kelompoknya atau masyarakat lingkunganya. Dalam sebuah komunitas berbasis tradisi ataupun modern, pendidikan Angklung ikut berperan serta dalam memelihara keseimbangan hidup dan meningkatkan kualitas hidup manusia. Peranan tersebut dapat diwujudkan dengan berbagai cara seperti:

1) Berperanan sebagai sebuah sistem penyebaran dalam masyarakat daerahnya dan luar daerahnya. Dalam komunitasnya, mereka melakukan eksplorasi (berpikir, berimajinasi, mempertimbangkan, menghayati) dan bereksperimen. Hal tersebut merupakan upaya untuk mengangkat nilai-nilai material dan spiritual dalam karyanya. Hasil karya yang sudah menjadi milik komunitas lingkungan kemudian disebarkan, disosialisasikan, dan dinikmati secara luas untuk memberi kepuasan batin kepada penikmatnya.

2) Melestarikan dan mengembangkan seni budaya bangsa. Berbabagi jenis Angklung, baik yang masih utuh/tradisi (Angklung Kanekes) hingga modern (Angklung Daeng/diatonis) sampai sekarang berkembang dengan baik di Tatar Sunda, bahkan di mancanegara, dan melalui perilaku kreatif dari para senimannya, kemudian ditransformasikan ke dalam berbagai bentuk seni lainnya. Perubahan-perubahan ini, baik Angklung tradisi maupun Angklung kreasi, disenangi oleh kalangan luas karena kehadirannya sesuai dengan selera perkembangan zaman. Terpeliharanya Angklung yang berbaur dengan berbagai jenis seni lainnya, hal ini dapat diartikan sebagai telah melestarikan salah satu seni budaya yang bisa menunjukkan identitas bangsa, yaitu Angklung itu sendiri.

3) Sebagai media pendukung komunikasi antarbangsa dan pelaksana diplomasi kebudayaan. Dalam rangka diplomasi budaya, Angklung sebagai satu bentuk seni yang dapat menunjukkan identitas bangsanya menjadi alat komunikasi dalam hubungan antara Indonesia dan bangsa-bangsa lain di dunia. Aktivitas pertunjukan Angklung, baik di dalam maupun di luar negeri, dapat membina kelancaran hubungan Indonesia dengan negara-negara lainnya. Berkembangnya musik Angklung modern (diatonis) di mancanegara (Eropa, Amerika, Asia, Afrika) berkat adanya usaha keras, baik dari kelompok maupun dari individu di lingkungan pendididkan di sekolah (SD, SMP, SMA, PT) juga dari luar sekolah (sangar, padepokan, lingkung seni, SAU/Saung Angklung Udjo, dsb.), telah memberikan pencitraan bagi bangsa Indonesia di luar negeri dan telah memberikan kesan bahwa bangsa Indonesia adalah bangsa yang mempunyai aneka ragam budaya. Berbagai misi kesenian yang telah dikirim ke luar negeri melalui musik Angklung ternyata memberi dampak yang cukup besar tehadap peningkatan adab berkesenian di Indonesia. Kini kesenian Indonesia tidak hanya dipelajari sebagai bagian dari kurikulum universitas-universitas di luar negeri, tetapi banyak ahli kesenian asing memasukkan esensi dari kesenian Indonesia ke dalam karyakarya kontemporer Barat. Dewasa ini masih banyak pesanan-pesanan instrumen Angklung dari luar negeri sebagai pertanda bahwa salah satu instrumen 
dan bentuk seninya sebagai kekayaan seni Indonesia mampu menjadi ajang promosi kebesaran seni dan seniman Indonesia.

4) Menumbuhkan rasa solidaritas budaya antarbangsa. Pameran atau pergelaran karya-karya musik Angklung diatonis (Angklung Daeng) di atas panggung ataupun televisi telah menumbuhkan apresiasi seni budaya yang semakin tinggi di kalangan masyarakat. Masyarakat Indonesia semakin merasa memiliki musik Angklung sebagai media yang dapat menumbuhkan rasa solidaritas antarbangsa di dalam pembangunan bangsa.

5) Memengaruhi perubahan sosial. Sarana pendidikan nonformal (sanggar, pedepokan, lingkung seni, dsb.) dapat bekerja sama dengan pihak pemerintah dan berperan untuk membangun masyarakat melalui pembinaan dan pengembangan dalam rangka memupuk dan merangsang aktivitas dan kreativitas dengan menggunakan media Angklung. Dalam hal ini, gedung-gedung pertunjukan, taman budaya, dan tempat-tempat lainnya yang berkaitan dengan kegiatan seni-budaya dapat dimanfaatkan sebagai pusat kegiatan, informasi seni, dan arena kreativitas.

Meningkatnya apresiasi masyarakat terhadap Angklung secara tidak langsung akan memupuk rasa bangga akan warisan budaya bangsa pada masa lampau, menyelamatkan, memelihara, dan meningkatkan peranan seni Angklung sebagai sarana pendidikan di luar sekolah. Kemudian, lebih jauh dari itu, kegiatan terebut dapat mewujudkan sumber daya manusia Indonesia yang berkualitas yang dicita-citakan oleh Pancasila, UUD 1945 dan GBHN.
Dengan demikian, kebijakan di bidang politik dan pendidikan pada umumnya harus diarahkan kepada kehidupan budaya yang berkaraker.

Berdasarkan kajian terhadap Angklung, baik sebagai alat musik maupun sebagai kesenian, dalam kaitannya dengan berbagai aspek fungsi, nilai, dan makna yang terkandung di dalamnya, tampaknya sangatlah tepat apabila Angklung dijadikan sebagai wahana pembentukan (pendidikan) karakter bangsa. Sebagai wahana pembentukan karakter bangsa, Angklung, baik dalam kapasitasnya sebagai alat musik maupun sebagai satu bentuk kesenian, harus mampu dijadikan sarana pembentukan karakter melalui proses pendidikan atau pembelajaran khususnya di sekolah-sekolah. Di sisi lain, seseorang (misalnya: pendidik atau pengajar) harus mampu menggali nilai-nilai yang terkandung dalam Angklung dan permainannya.

Berkaitan dengan nilai-nilai yang terkandung dalam Angklung, baik dalam bentuk fisik Angklung maupun dalam permainan Angklung adalah sebagaimana telah dibahas sebelumnya. Akan tetapi untuk lebih mendalami pemahaman tentang sejauh mana permainan Angklung dapat dijadikan sebagai sarana pembentukan karakter, dilakukan analisis terhadap proses pembelajaran Angklung yang dilakukan oleh salah seorang anggota peneliti, Abun Somawijaya, terhadap siswa SMA Banjaran Kelas 10 dan 11 yang menjadi objek penelitian.

Proses pembelajaran Angklung tersebut terkandung dalam DVD 2 yang berjudul "Permainan Angklung Sebagai Wahana Pembentukan Karakter". Di dalam DVD 2 tersebut ada lima lagu yang dijadikan sampel pembelajaran, yaitu: Terima 
Kasihku, Bungo Jeumpa, Mother How Are You Today, Rindu Lukisan, dan Donau Wellen. Akan tetapi yang dianalisis hanya satu saja, lagu Terima Kasihku, karena kalaupun dilakukan terhadap yang lainnya hasil analisisnya akan relatif sama.

Dalam DVD 2 tersebut, Abun Somawijaya melakukan pembelajaran Angklung terhadap para siswa kelas 10 yang belum pernah memainkan Angklung. Proses pembelajaran yang dilakukannya terdiri dari beberapa tahap sebagai berikut:

Pertama, Pengajar (Abun Somawijara) menjelaskan tentang jenis Angklung yang terdiri dari dua jenis, yaitu Angklung pentatonis (laras salendro) dan Angklung diatonis (tangga nada musik Barat). Angklung pentatonis adalah Angklung zaman dulu, menggunakan laras salendro, dan biasa dipertunjukkan dalam acara hajatan seperti perkawinan, sunatan, dan upacara-upacara, contohnya di antaranya adalah Angklung Buncis dan Angklung Sered. Kemudian Angklung diatonis, menggunakan tangga nada musik Barat: do re mi fa sol la ti do atau C D E F G A B C'.

Kedua, pengajar memfokuskan pembelajarannya pada Angklung diatonis. Angklung diatonis ini memiliki tanda yang berupa abjad (A B C D E F G dst.) dan angka (1 234567 dst.). Untuk mempermudah dalam memilih Angklung, Angklung yang memiliki tanda berupa huruf besar dan angka tersebut diberi nomor dengan menggunakan nomor angka. Selanjutnya pengajar menjelaskan tentang bagaimana cara melakukan penomoran pada Angklung. Pengajar menjelaskan bahwa Angklung itu terbagai ke dalam tiga unit, yaitu: Angklung unit besar (AUB), Angklung unit sedang (AUS), dan Angklung unit kecil (AUK). Dalam Angklung unit besar tersebut ada Angklung melodi kecil dan Angklung melodi besar. Kemudian Angklung pengiringnya terdiri dari: accompaniment dan co-accompaniment yang terbagi lagi atas accompniment/co-accompaniment mayor (Angklung empat tabung) dan minor (Angklung tiga tabung).

Ketiga, pengajar menjelasakan bahwa dalam permainan Angklung, instrumennya terbagi atas: instrumen pokok dan instrumen tambahan. Instrumen pokok terdiri dari: Angklung melodi (melodi kecil dan melodi besar) dan Angklung pengiring (accompaniment dan co-accompaniment), sedangkan instrumen tambahan terdiri dari: contra bass, cello, symbal, dan conga.

Keempat, pengajar menjelaskan tentang penomoran Angklung. Angklung melodi kecil diberi nomor mulai dari 0 (Angklung terbesar, nadanya Fis) sampai dengan 30 (Angklung terkecil, nadanya $\mathrm{c}^{\prime \prime}$ ), sehingga jumlahnya ada 31 Angklung. Kemudian Angklung melodi besar diberi tanda dari mulai huruf $G$ sampai dengan F, ada 11 Angklung. Angklung F ini menyambung dengan Angklung nomor 0 tadi. Dalam Angklung unit besar, Angklung melodi kecil terdiri dari 3 set, sehingga jumlahnya menjadi 93 Angklung; dan Angklung melodi besar terdiri dari 2 set, sehingga jumlahnya menjadi 22 Angklung.

Kelima, pengajar melakukan praktik memainkan Angklung lagu Terima Kasih$k u$. Pembelajaran praktik memainkan Angklung ini diawali dengan penjelasan mengenai teknik memegang Angklung. Tangan kiri dipakai untuk menggantungkan Angklung dengan posisi telapak tangan mengarah ke bawah atau mengarah ke atas; sedangkan tangan kanan digunakan untuk menggoyangkan (membunyikan) Angklung. Bunyi Angklung 
ada yang pendek dan ada yang panjang. Bunyi pendek dihasilkan dari menggoyangkan Angklung secara sebentar saja; sedangkan bunyi panjang dihasilkan dari menggoyangkan Angklung secara secara terus-menerus (lama). Kemudian pengajar juga menjelaskan tentang nada-nada Angklung dalam kaitannya dengan penomoran Angklung. Selesai penjelasan, barulah dilanjutkan dengan belajar memainkan Angklung lagu Terima Kasihku.

Setelah diamati secara cermat, praktik memainkan Angklung lagu Terima Kasih$k u$ menunjukkan adanya nilai-nilai yang dapat membentuk karakter posistif yang tentu saja identik dengan karakter bangsa. Nilai-nilai tersebut antara lain meliputi nilai: 1) kebersamaan, 2) kekompakan, 3) kerja sama, 4) saling menghargai, dan 5) tanggung jawab.

Musik Angklung merupakan sebuah ensambel yang terdiri dari sejumlah besar alat musik, yaitu Angklung. Setiap Angklung dimainkan oleh satu orang. Dengan demikian, kesuksesan permainan Angklung sangat bergantung pada individu pemainnya. Oleh karena itu, untuk menghasilkan permainan yang baik dan indah diperlukan kebersamaan. Kebersamaan yang dimaksud di sini adalah kebersamaan dalam arti kesatuanpaduan pemikiran dan perasaan di antara para pemain untuk memiliki niat/keinginan untuk dapat memainkan Angklung dengan baik dan benar serta indah. Dengan berlandaskan pada rasa kebersamaan inilah para pemain akan berupaya untuk melakukan sikap dan tindakan-tindakan lainnya demi kesuksesan permainan Angklungnya. Sikap dan tindakan-tindakan dimaksud dimulai dari adanya rasa tanggung jawab pada setiap individu pemain. Setiap pemain akan merasa bertanggung jawab atas: alat musik yang dipegangnya, bagian-bagian nada yang dimainkannya, permainan Angklungnya yang baik dan benar. Dari sikap dan tindakan yang dilandasi rasa tanggung jawab masing-masing individu ini kemudian akan melahirakan sikap dan tindakan saling menghargai di antara pemain. Dalam memainkan Angklungnya, setiap individu pemain akan mematuhi ketentuan partitur lagu sekaligus juga menunggu dan mempersilakan bagian orang lain, dalam arti menghargai/ menghormati hak atau bagian orang lain untuk membunyikan Angklungnya. Dengan demikian, dengan sendirinya ia pun akan memainkan/membunyikan Angklungnya dengan tepat sesuai dengan partitur lagu yang dimainkannya. Oleh karena masing-masing individu sudah bisa saling menghargai, yang muncul selanjutnya adalah kerja sama di antara pemain. Dari sikap dan tindakan saling menghargai, para pamain kemudian akan mampu membangun kerja sama dalam memainkan Angklung. Kemuidan, dari tindakan kerja sama ini pada akhirnya akan muncul kekompakan. Para pemain akan memainkan Angklungnya dengan kompak untuk mencapai permainan Angklung yang baik dan benar serta indah.

Nilai-nilai kebersamaan, tanggung jawab, sikap saling menghargai, kerja sama, dan kekompakan di antara pemain Angklung ketika memainkan lagu Terima Kasihku sungguh merupakan nilai-nilai vital yang akan membentuk karakter (bangsa) yang positif. Nilai-nilai seperti ini amat diperlukan oleh masyarakat Sunda dan masyarakat Indonesia pada umumnya dalam upayanya membangun kembali identitas atau jati dirinya sebagai masyarakat Sunda sekaligus sebagai bangsa Indonesia. Dengan nilai-nilai seperti inilah iden- 
titas, kesatun, dan persatuan bangsa akan terpelihara. Dengan demikian, dapatlah ditarik kesimpulan bahwa permainan musik Angklung dapat dijadikan sebagai wahana pembentukan karakter bangsa.

\section{PENUTUP}

Angklung Sunda, baik Angklung tradisi maupun Angklung "modern", dapat difungsikan sebagai wahana industri kreatif dan wahana pembentukan karakter bangsa. Hal ini terbukti dari ditemukannya nilai-nilai fungsional (sebagai media upacara/ritual, pendidikan, hiburan) dan makna (filosofis, religius, kultutral, ekonomis) yang terkandung dalam Angklung, baik dalam kapasitasnya sebagai alat musik maupun dalam kapasitasnya sebagai satu bentuk kesenian (seni pertunjukan).

Sebagai wahana industri kreatif, sebagaimana telah diperlihatkan oleh Saung Angklung Udjo, Angklung dapat diproduksi dalam berbagai bentuk dan variasi, baik sebagai alat musik untuk kebutuhan pertunjukan maupun sebagai bentuk kerajinan atau hiasan untuk kebutuhan suvenir atau cinderamata. Dalam hal ini, Angklung sebagai objek/materi industri kreatif (sebagai alat musik dan seni pertunjukan) telah mampu menjadi sumber penghasilan finansial sehingga turut andil dalam meningkatkan kesejahteraan ekonomi masyarakat, khususnya individu-individu yang terlibat dalam produksi dan pertunjukan Angklung, dari yang memiliki kebun bambu untuk bahan Angklung, para pembuat/pengrajin Angklung, masyarakat di sekitar Saung Angklung Udjo, para seniman (penggarap dan pemain Angklung), hingga pemilik in- dustri Angklung itu sendiri-Saung Angklung Udjo.

Sebagai wahana pembentukan karakter bangsa, Angklung dapat difungsikan dalam pendidikan (pembelajaran dan latihan), baik di dalam maupun di luar institusi pendidikan (sekolah-sekolah). Dalam hal ini, baik sebagai alat musik (fisik) maupun sebagai seni pertunjukan (nonfisik), Angklung telah turut andil dalam menyumbangkan pemahaman akan berbagai nilai dan makna yang terkandung di dalamnya sebagai bagian dari perangkat karakter bangsa, baik kapada orang Sunda khususnya maupun kepada orang Indonesia pada umumnya. Katakter bangsa inilah yang kemudian diharapkan akan termanifestasikan dalam bentuk pandangan, sikap, dan perilaku anggota masyarakat sebagai bangsa Indonesia, yakni bangsa Indonesia yang berkarakter dan berjati diri.

Berdasarkan hasil penelitian dapat dikemukakan saran-saran yang diperuntukkan bagi berbagai pihak, khususnya institusi-institusi yang berkaitan dengan penelitian Angklung, seperti institusi pendidikan, kebudayaan, kesenian, pariwisata, dan juga masyarakat, sebagai berikut:

1) Sebagaimana telah diketahui bahwa Angklung merupakan satu jenis kesenian yang baru-baru ini telah mendapat pengakuan dari UNESCO sebagai salah satu dari the Intangible Culture Herritage, yang sudah menjadi identitas budaya bangsa Indonesia yang diangap penting. Oleh sebab itu, tampaknya sudah menjadi kewajiban bagi masyarakat Indonesia, khususnya institusi-institusi pendidikan, kebudayaan, kesenian, dan pariwisata, baik di daerah maupun di pusat untuk bersama-sama memelihara dan mengembangkan kesenian 
Angklung ini, agar Angklung tetap menjadi kebanggaan dan identitas budaya bangsa Indonesia.

2) Bekaitan dengan industri kreatif, sudah saatnya institusi-institusi lain, selain Saung Angklung Udjo, untuk mencoba memberdayakan Angklung sebagai wahana industri kreatif, karena setelah dilakukan penelitian, diyakini bahwa Angklung merupakan salah satu bentuk kesenian yang memiliki potensi besar untuk dijadikan sebagai objek industri kreatif dalam rangka membantu meningkatkan kesejahteran ekonomi masyarakat.

3) Berkaitan dengan pendidikan karakter, sudah saatnya pula institusi-institusi terkait untuk lebih memberdayakan Angklung sebagai wahana pendidikan karakter dalam rangka membantu upaya pemerintah dalam membentuk serta memperkokoh karatkter bangsa, menuju kehidupan bangsa Indonesia yang berkarakter dan berjati diri. Untuk itu perlu dicari dan diciptakan strategi-strategi pelaksanaannya, salah satunya melalui pembelajaran Angklung di sekolah-sekolah dan juga di masyarkat.

\section{CATATAN AKHIR:}

i Tulisan ilmiah yang berjudul "Angklung Sunda Sebagai Wahana Industri Kreatif dan Pembentukan Karakter Bangsa" ini merupakan hasil penelitian yang dilakukan oleh: Deni Hermawan (penulis) sebagai ketua peneliti; Abun Somawijaya, Dinda Satya Upaja Budi, Ucu Mulya Santosa, dan Iyon Supiono, sebagai anggota peneliti; dalam rangka Hibah Penelitian Unggulan Dikti 2012.

ii Uraian mengenai pertunjukan Ang- klung badud dan Angklung badeng ini bersumber dari hasil penelitian Juju Masunah, dkk., dalam bukunya yang berjudul Angklung di Jawa Barat: Sebuah Perbandingan," IKIP Bandung, 1999, hlm. 49, 58, dan 59.

iii Mircea Eliade, The Sacred and The Profane: The Nature of Religion. Tranlated from the French by Willard R. Trask. (New York: The Harvest Book Harcourt, Brace, \& World. Inc., 1959), 35-37.

\section{DAFTAR PUSTAKA}

Abun Somawijaya

1995 "Angklung Buhun, Sebuah Telusuran Awal." Laporan Penelitian. Bandung: Puslitmas ASTI Bandung.

Anis Djatisunda

1992/1993 Baduy Rawayan Urang Kanekes. Sukabumi: Pemerintah Propinsi Daerah Tingkat I Jawa Barat, Dinas Pendidikan dan Kebudayaan, Proyek Pengembangan serta Penataran Pendidik Bahasa dan Sastra Sunda.

A. S. Marcus

1986 Kehidupan Suku Baduy. Bandung: CV Rosda.

Atik Soepandi, dkk.

1995 Ragam Cipta: Mengenal Seni Pertunjukan Daerah Jawa Barat. Bandung: CV Beringin Sakti.

Dinda Satya Upaja Budi

2001 "Angklung Baduy dalam Upacara Ritual Ngaseuk.” Tesis. Program Studi Pengkajian Seni 
Pertunjukan dan Seni Rupa Program Pascasarjana Universitas Gadjah Mada.

Djoewisno M. S.

1988 Potret Kehidupan Masyarakat Baduy. Jakarta: Khas Studio.

Ganjar Kurnia dan Arthur S. Nalan

2003 Deskripsi Kesenian Jawa Barat. Bandung: Kerjasama Dinas Kebudayaan dan Pariwisata Jawa Barat dengan Pusat Dinamika Pembangunan UNPAD.

Jakob Sumardjo

2011 Sunda: Pola Rasionalitas Budaya. Bandung: Kelir.

Juju Masunah, dkk.

2003 Angklung di Jawa Barat: Sebuah Perbandingan. Pendidikan Kesenian Buku 1. Cetakan Kedua. Bandung: Departemen Pendidikan dan Kebudayaan Institut Keguruan dan Ilmu Pendidikan Bandung.

Said Hamid Hasan, dkk.

2010 Pengembangan Pendidikan Budaya dan Karakter Bangsa. Jakarta: Kemdiknas Badan Penelitian dan Pengembangan Pusat kurikulum.

http://juprimalino.blogspot.com/2012/03/ pengertian-pendidikan-karakter-bangsa. html

http://www.pelita.or.id/baca. php?id=40111 